Research Article

\title{
The Influence of Common Carp Meat (Cyprinus carpio) Diet on Brain Index and The Expression of Gene NR2B of Swiss Webster Mice Cerebrum
}

\author{
Philips Onggowidjaja*, M. Nurhalim Shahib ${ }^{* *}$ \\ ${ }^{*}$ Department of Microbiology, Faculty of Medicine Maranatha Christian University, \\ Jln. Prof. Drg. Suria Sumantri MPH no 65 Bandung 40163 Indonesia \\ ${ }^{* * 2}$ Faculty of Medicine Padjadjaran University, \\ Jln. Eijckman no 38 Bandung 40161 Indonesia \\ Email: philips.onggowidjaja@yahoo.com
}

\begin{abstract}
This research was to evaluate the influence of common carp meat diet on brain index and gene NR2B expression of Swiss Webster mice cerebrum. The gene expression and performance of ion $\mathrm{Ca}^{2+}$ channel in neuron are influenced by Glycine and Glutamic Acid, which present in relatively high quantities in common carp meat. Eighteen male mice were divided into 3 diet groups, the standard pellet, $120 \mathrm{mg}$ and $480 \mathrm{mg}$ common carp meat/day. The brain index differences among groups were analyzed using ANOVA test $(p \leq 0,05)$ and LSD. The total RNA of $5 \mathrm{mg}$ mouse cerebrum was isolated, followed by RT-PCR; the DNA quantities were predicted using Geldoc instrument, then were analyzed using ANOVA test $(p \leq 0,05)$. The 120 $m g$ diet group brain index did not show difference $(p=0,284)$ against the standard diet group, while the $480 \mathrm{mg}$ diet group showed the increase compared to the standard $(p=0,034)$ and 120 $m g$ diet groups $(p=0,004)$. No DNA quantity differences of all groups $(p=0,195)$. It was concluded, the $480 \mathrm{mg}$ common carp meat/ day diet increased the brain index of Swiss Webster mice, while the $120 \mathrm{mg}$ and $480 \mathrm{mg}$ common carp/day diets did not influence the gene NR2B expression of Swiss Webster mice cerebrum.
\end{abstract}

Keywords : brain index, gene NR2B expression, common carp meat diet 


\title{
Pengaruh Diet Daging Ikan Mas (Cyprinus Carpio) terhadap Indeks Otak dan Ekspresi Gen NR2B pada Serebrum Mencit Swiss Webster
}

\author{
Philips Onggowidjaja*, M. Nurhalim Shahib ${ }^{* *}$ \\ *Bagian Mikrobiologi, Fakultas Kedokteran Universitas Kristen Maranatha, \\ Jln. Prof. Drg. Suria Sumantri MPH no 65 Bandung 40163 Indonesia \\ ${ }^{* *}$ Fakultas Kedokteran Universitas Padjadjaran, \\ Jln. Eijkman no 38 Bandung 40161 Indonesia \\ Email: philips.onggowidjaja@yahoo.com
}

\begin{abstract}
Abstrak
Penelitian ini bertujuan mengevaluasi pengaruh diet daging ikan mas terhadap indeks otak dan ekspresi gen $N R 2 B$ pada serebrum mencit Swis Webster. Ekspresi gen NR2B dan kerja pori ion $\mathrm{Ca}^{2+}$ pada neuron dipengaruhi oleh Glisin dan Asam Glutamat yang terdapat dalam konsentrasi relatif tinggi pada daging ikan mas. Sebanyak 18 ekor mencit jantan dibagi ke dalam 3 kelompok perlakuan diet, yaitu pakan standar, $120 \mathrm{mg}$ dan $480 \mathrm{mg}$ daging ikan mas/hari. Perbedaan indeks otak antar kelompok dianalisis dengan uji Anava $(p \leq 0,05)$ dan LSD. RNA total dari $5 \mathrm{mg}$ otak besar tiap mencit diisolasi dan dilakukan RT-PCR; jumlah DNA-nya diperkirakan dengan alat Geldoc lalu dianalisis dengan uji Anava $(\mathrm{p} \leq 0,05)$. Indeks otak kelompok diet $120 \mathrm{mg}$ tidak menunjukkan perbedaan $(\mathrm{p}=0,284)$ dari kelompok diet standar, sedangkan indeks otak kelompok diet $480 \mathrm{mg}$ menunjukkan peningkatan dibandingkan kelompok standar $(\mathrm{p}=0,034)$ dan kelompok diet $120 \mathrm{mg}(\mathrm{p}=0,004)$. Tidak ada perbedaan jumlah DNA $(p=0,195)$ pada semua kelompok perlakuan. Simpulan dari penelitian ini, diet daging ikan mas $480 \mathrm{mg} / \mathrm{hari}$ dapat meningkatkan indeks otak mencit Swiss Webster, namun diet daging ikan mas $120 \mathrm{mg} / \mathrm{hari}$ maupun $480 \mathrm{mg} /$ hari tidak berpengaruh terhadap ekspresi gen $N R 2 B$ pada serebrum mencit Swiss Webster.
\end{abstract}

Kata kunci: indeks otak, ekspresi gen NR2B, diet daging ikan mas 


\section{Research Article}

\section{Pendahuluan}

NR2B sebagai protein subunit yang menyusun saluran ion $\mathrm{Ca}^{2+}$ pada neuron, berperan setidaknya dalam dua fungsi pada neuron, yaitu sebagai penentu tingkat kecerdasan dan sebagai agen perantara pada berbagai mekanisme patologik. ${ }^{1,2,3,4,5,6}$

Di lain pihak, ada faktor nutrisi yang menentukan ekspresi gen $N R 2 B$ dan aktivitas subunit ini. ${ }^{7}$ Faktor nutrisi ini adalah asam amino Glisin dan Asam Glutamat yang terdapat dalam jumlah yang relatif banyak pada beberapa jenis makanan tertentu. Karena aktivasi subunit ini dalam memasukkan ion $\mathrm{Ca}^{2+}$ ke dalam neuron membutuhkan kehadiran kedua asam amino tersebut secara bersamaan ${ }^{8}$, maka bahan makanan yang mengandung keduanya dalam jumlah relatif besar diperkirakan dapat meningkatkan influks $\mathrm{Ca}^{2+}$ ke dalam neuron, yang pada gilirannya dapat menyebabkan apoptosis ${ }^{5}$ (Gambar 1).

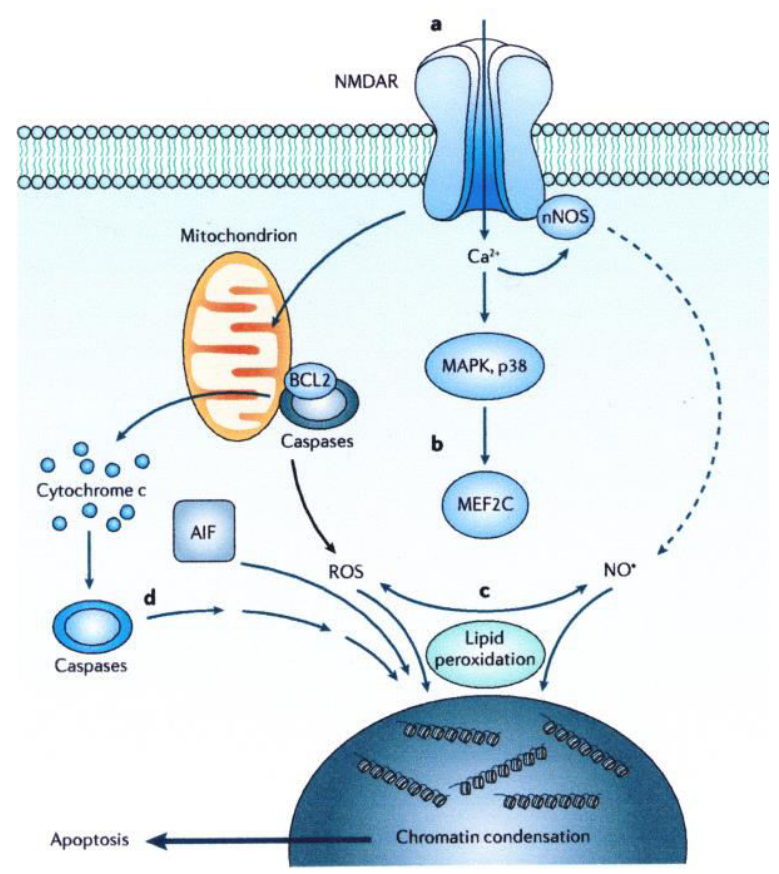

Gambar 1 Skema cedera sel apoptotik dan jalur kematian sel yang dipicu oleh aktivitas NMDAR yang berlebihan ${ }^{5}$

Salah satu bahan makanan yang memiliki kandungan Glisin dan Asam Glutamat relatif lebih tinggi daripada bahan makanan lain, adalah daging ikan mas ${ }^{9}$ yang banyak dan umum dijumpai maupun dikonsumsi di Indonesia, bahkan di seluruh dunia. Peran bahan makanan tidak hanya untuk mempertahankan kelangsungan hidup sebagai sumber energi dan untuk mempertahankan fungsi normal tubuh, tetapi juga berpengaruh terhadap kesehatan, baik yang 


\section{Research Article}

menguntungkan maupun yang merugikan. Pengaruh bahan makanan terhadap ekspresi gen, dalam hal ini pengaruh Glisin dan Asam Glutamat yang terdapat di dalam daging ikan mas terhadap ekspresi gen $N R 2 B$ pada serebrum mencit Swiss Webster dikaji dalam penelitian ini.

\section{Metode}

Mencit Swiss Webster jantan usia 51 hari, dengan berat badan $23 \pm 1$ g digunakan sebanyak 18 ekor, diperoleh dari fasilitas pemeliharaan mencit pada Sekolah Ilmu dan Teknologi Hayati (SITH) Institut Teknologi Bandung (ITB). Pakan standar untuk mencit dibuat oleh petugas di Lab. Hewan Departemen Farmakologi \& Terapi Fakultas Kedokteran Universitas Padjadjaran. Ikan mas sebagai bahan diet dibeli di sebuah pasar tradisional di Bandung, berasal dari peternakan ikan di Waduk Cirata, dikerok dagingnya, lalu ditimbang dan ditambah air sesuai takaran diet dan teknis pemberian dengan sonde. Otak mencit diawetkan dengan larutan RNAlater (Ambion Inc.) hingga waktu digunakan. RNA total otak mencit diisolasi menggunakan MagMAX 96 Total RNA Isolation Kit (Ambion Inc. cat \# AM 1830), sedangkan Reverse Transcription-Polymerase Chain Reaction (RT-PCR) dan PCR dilakukan menggunakan kit Access RT-PCR System Promega (satu langkah). Hasil PCR dielektroforesis, lalu dibaca dengan alat Gel Doc ${ }^{\mathrm{TM}}$ EZ Imager BioRad, diperkirakan jumlah dan ukurannya menggunakan marker EZ Load Precision Molecular Mass Standard.

Seluruh mencit dipelihara di Lab. Hewan Departemen Farmakologi \& Terapi Fakultas Kedokteran Universitas Padjadjaran, mendapatkan akses bebas untuk pakan standar dan air minum selama 7 hari masa adaptasi maupun selama perlakuan diet. Selanjutnya, 18 mencit dibagi ke dalam 3 kelompok perlakuan diet (masing-masing terdiri atas 6 ekor), yaitu diet pakan standar penuh, diet daging ikan mas (mentah) $120 \mathrm{mg} / \mathrm{hari}$, dan $480 \mathrm{mg} / \mathrm{hari}$. Pemberian diet daging ikan mas dilakukan dengan sonde oral (daging ikan dihancurkan dan dicampur $1 \mathrm{~mL}$ air), setengah porsi diberikan pagi dan sisanya sore. Berat badan mencit dipantau setiap minggu. Setelah diet 30 hari, mencit diterminasi dengan teknik dislokasi leher, lalu berat badannya ditimbang. Kepala mencit dibedah untuk diambil otaknya, dan berat total otak ditimbang. Indeks otak dihitung sebagai persentase rasio berat total otak terhadap berat badan (Dian Anggraeni, Efek Infusa Kacang Kedelai terhadap Memori Spasial dan Indeks Otak Mencit Galur Swiss Webster, skripsi, 2009, tidak dipublikasikan). Untuk pekerjaan molekuler, hanya otak besar (serebrum) yang diambil, seluruhnya dimasukkan ke dalam tabung Eppendorf 1,5 mL berisi larutan RNAlater $350 \mathrm{~mL}$ hingga terendam seluruhnya. Untuk isolasi RNA total, kira-kira $2 \mathrm{~mm}^{2}$ (atau $5 \mathrm{mg}$ ) serebrum diiris dari stok otak, dicuci dengan larutan $\mathrm{NaCl}$ fisiologik, lalu diproses sesuai protokol dari kit. RNA total hasil isolasi diukur kemurnian dan 


\section{Research Article}

kadarnya menggunakan spektrofotometer UV. Hasil isolasi digunakan sebagai template untuk RT-PCR dan PCR yang berlangsung dalam satu campuran dan satu proses PCR menggunakan pasangan primer $\mathrm{F}$ ggtagccatgaacgagactg maupun $\mathrm{R}$ ttcacgaagtcctggtagcc, dengan gen GAPDH (F tcggtgtgaacggatttggc, R gcttccegttgatgacaagc) sebagai kontrol PCR. Hasil PCR kedua gen dari setiap sampel dielektroforesis; marker dari Promega yang digunakan dapat menunjukkan ukuran fragmen yang diamplifikasi (satuan pb (pasang basa)) sekaligus jumlah DNA (satuan ng) melalui perbandingan kecerahan yang dibaca menggunakan alat Geldoc. Jumlah DNA yang berbanding lurus dengan banyaknya mRNA dari sampel dihitung berdasarkan rumus dari manual marker EZ Load Precision Molecular Mass Standard, sebagai berikut :

$$
\text { Jumlah DNA (ng) }=\frac{\frac{\text { Vol. intensitas sampel }}{\text { Vol. intensitas standar }} \times \text { Kadar standar }}{5 \mu \mathrm{L}}
$$

Hasil perhitungan indeks otak maupun jumlah DNA dianalisis dengan uji Anava (dan LSD untuk indeks otak).

\section{Hasil \& Diskusi}

Pengaruh diet daging ikan mas terhadap perubahan massa otak ditunjukkan oleh rerata indeks otak mencit yang disajikan dalam Tabel 1. Analisis statistik ANAVA atas tiga perlakuan diet menunjukkan perbedaan yang signifikan dengan nilai $\mathrm{p}=0,011$. Analisis LSD menunjukkan perbedaan yang signifikan itu terjadi pada perbandingan diet seperti disajikan dalam Tabel 2.

Tabel 1 Indeks Otak Mencit pada Tiga Perlakuan Diet

\begin{tabular}{cccc}
\hline \multirow{2}{*}{ No } & \multicolumn{3}{c}{ Diet } \\
\cline { 2 - 4 } & Standar & $\mathbf{1 2 0} \mathbf{~ m g} / \mathbf{h a r i}$ & $\mathbf{4 8 0} \mathbf{~ m g} / \mathbf{h a r i}$ \\
\hline 1 & 1,55 & 1,32 & 1,54 \\
2 & 1,17 & 1,37 & 1,45 \\
3 & 1,42 & 1,28 & 1,95 \\
4 & 1,32 & 1,00 & 1,86 \\
5 & 1,47 & 1,30 & 1,80 \\
6 & 1,79 & 1,66 & 1,78 \\
\hline Rerata & $1,45 \pm 0,21$ & $1,32 \pm 0,21$ & $1,73 \pm 0,19$ \\
\hline
\end{tabular}


Tabel 2 Hasil Analisis LSD Indeks Otak Mencit

\begin{tabular}{|c|c|c|}
\hline \multicolumn{2}{|c|}{ Perbandingan } & \multirow{2}{*}{ Signifikansi (p) } \\
\hline Diet A & Diet B & \\
\hline Diet standar & Diet 120 & 0,284 \\
\hline & Diet 480 & $0,034 *$ \\
\hline Diet 120 & Diet 480 & $0,004 *$ \\
\hline
\end{tabular}

$*=$ hasil perbandingan yang signifikan

Berdasarkan data pada Tabel 1, terdapat penurunan massa otak relatif terhadap berat badan, antara diet standar dan diet $120 \mathrm{mg} /$ hari, namun penurunan ini tidak signifikan (Tabel 2). Meskipun demikian, kecenderungan penurunan ini diduga disebabkan oleh kandungan asam amino Glisin dan Asam glutamat dalam diet daging ikan mas menstimulasi aktivitas NR2B secara berlebihan sehingga menyebabkan neuron mengalami apoptosis ${ }^{5}$ dan berakhir dengan penurunan masa otak. Sebaliknya, terdapat peningkatan indeks otak yang signifikan antara diet standar maupun diet 120 terhadap diet $480 \mathrm{mg} / \mathrm{hari}$. Penyebab peningkatan ini belum dapat dijelaskan.

Hasil elektroforesis sampel DNA hasil RT-PCR dari RNA serebrum mencit disajikan dalam Gambar 2, Gambar 3, dan Gambar 4 berikut ini.
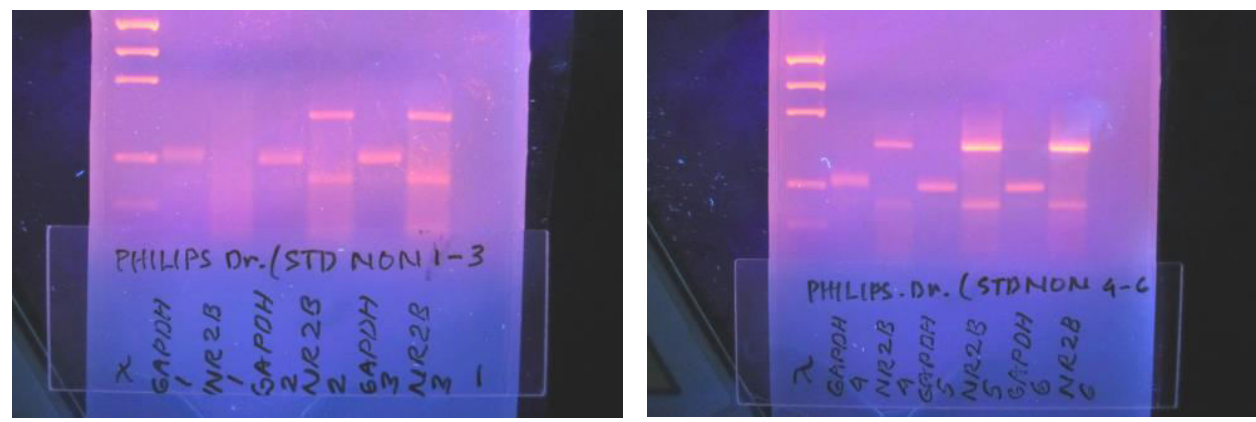

Gambar 2 Hasil Elektroforesis DNA Serebrum Mencit Diet Standar (Sampel 1-6)
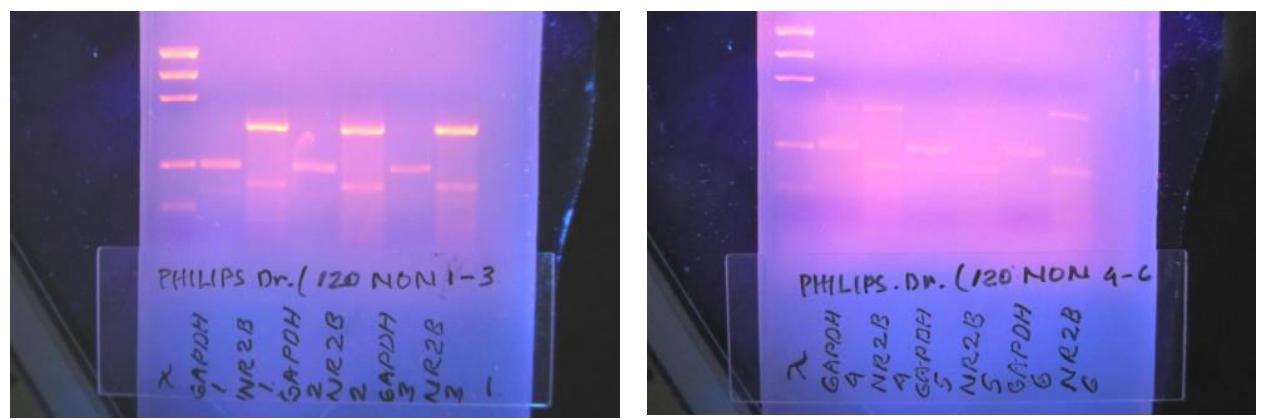

Gambar 3 Hasil Elektroforesis DNA Serebrum Mencit Diet Daging Ikan Mas 120mg/hari (Sampel 1-6) 

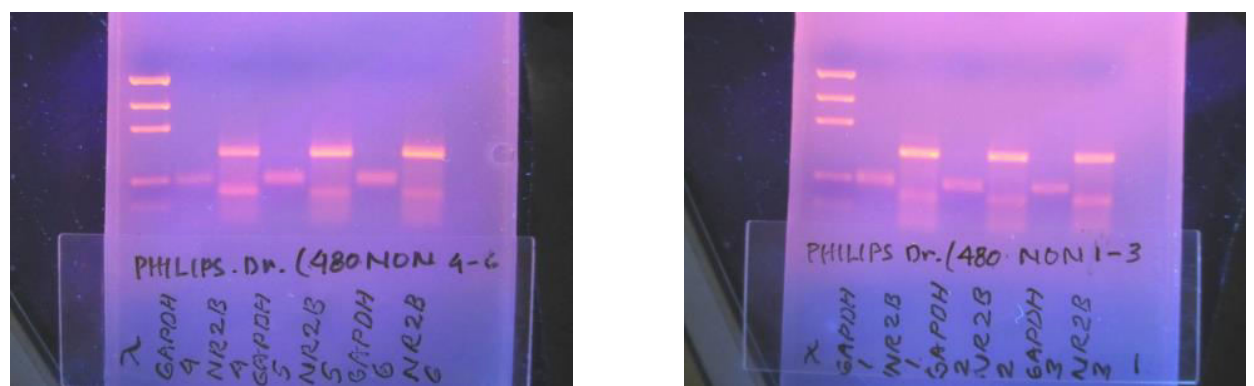

\section{Gambar 4 Hasil Elektroforesis DNA Serebrum Mencit Diet Daging Ikan Mas 480mg/hari (Sampel 1-6)}

DNA dari gen $G A P D H$ muncul sebagai pita berukuran $200 \mathrm{pb}$, sedangkan gen $N R 2 B$ muncul sebagai pita berukuran $341 \mathrm{pb}$.

Pengaruh diet daging ikan mas terhadap ekspresi gen $N R 2 B$ pada serebrum mencit ditunjukkan oleh jumlah DNA hasil PCR, disajikan dalam Tabel 3 berikut ini. Analisis statistik ANAVA menunjukkan nilai $p=0,195$. Hasil ini menunjukkan tidak terdapat perbedaan yang signifikan pada semua perlakuan diet. Penjelasan fenomena ini, bahwa diet daging ikan mas dengan kandungan asam amino Glisin dan Asam glutamatnya tidak mempengaruhi ekspresi gen $N R 2 B$ pada serebrum mencit.

Tabel 3 Jumlah DNA Hasil PCR

\begin{tabular}{ccccccc}
\hline \multirow{2}{*}{ No } & \multicolumn{7}{c}{ Diet } \\
\cline { 2 - 6 } & \multicolumn{7}{c}{ Pakan standar } & Ikan mas 120 mg/hari & \multicolumn{2}{c}{ Ikan mas 480 mg/hari } \\
\cline { 2 - 6 } & GAPDH & NR2B & GAPDH & NR2B & GAPDH & NR2B \\
\hline 1 & 4,12 & - & 5,94 & 36,70 & 8,46 & 28,99 \\
2 & 9,60 & 5,98 & 5,49 & 34,97 & 7,90 & 25,47 \\
3 & 8,80 & 8,54 & 3,36 & 49,37 & 6,50 & 21,25 \\
4 & 5,60 & 4,16 & 13,47 & 11,45 & 2,72 & 11,34 \\
5 & 5,40 & 22,58 & 6,03 & 3,83 & 7,69 & 26,13 \\
6 & 5,12 & 23,54 & 9,19 & 3,12 & 8,04 & 28,84 \\
\hline Rerata & \multicolumn{7}{c}{23,67} \\
\hline Catatan : & pemeriksaan ekspresi gen GAPDH sebagai house keeping gene berfungsi sebagai kontrol proses RT-PCR \\
• & tanda '- berarti tidak ada data.
\end{tabular}

Kehadiran asam amino Glisin dan Asam Glutamat pada daging ikan mas menstimulasi influks $\mathrm{Ca}^{2+}$, menyebabkan efek patologik sehingga terjadi penurunan masa otak yang tidak signifikan pada penelitian ini, namun belum cukup untuk meningkatkan ekspresi gen $N R 2 B$.

Beberapa penelitian yang relevan dan dapat dilakukan, misalnya pengaruh diet daging ikan mas terhadap ekspresi gen $N R 2 A$ yang bersifat neuroprotektif dan pengaruh diet berbagai 


\section{Research Article}

bahan makanan kaya Glisin dan Asam Glutamat lain terhadap ekspresi gen NR2B pada otak atau kerja neuron. Meskipun demikian, penderita berbagai gangguan otak (epilepsi, stroke, hipoksia, dll) masih perlu mengikuti diet sehat rendah Glisin dan Asam Glutamat untuk mencegah atau mengurangi risiko kerusakan otak lebih lanjut. ${ }^{10}$

\section{Simpulan}

Diet daging ikan mas $480 \mathrm{mg} / \mathrm{hari}$ dapat meningkatkan indeks otak mencit Swiss Webster, namun diet daging ikan mas $120 \mathrm{mg} / \mathrm{hari}$ maupun $480 \mathrm{mg} / \mathrm{hari}$ tidak berpengaruh terhadap ekspresi gen $N R 2 B$ pada serebrum mencit Swiss Webster.

\section{Daftar Pustaka}

1. Gascon S, Sobrado M, Roda JM, Pena AR, Guerra MD. Excitotoxicity and Focal Cerebral Ischemia Induce Truncation of the NR2A and NR2B subunits of the NMDA Receptor and Cleavage of the Scaffolding Protein PSD-95. Mol Psychiatry. 2008;13:99-114

2. Lynch MA. Long-term Potentiation and Memory. Physiol Rev. 2004;84:87-136

3. Sobolevsky AI, Prodromou ML, Yelshansky MV, Wollmuth LP. Subunit-specific Cntribution of Pore-forming Domains to NMDA Receptor Channel Structure and Gating. J Gen Physiol. 2007; 129(6): 509-25

4. Arifin MZ, Faried A, Shahib MN. Inhibition of Activated NR2B gene- and caspase-3 protein-expression by Glutathione Following Traumatic Brain Injury in A Rat Model. Asian J Neurosurg. 2011; 6(2): 72-7

5. Lipton SA. Paradigm Shift in Neuroprotection by NMDA Receptor Blockade: Memantine and Beyond. Nat Rev. (Drug Discovery). 2006; 5: 160-70

6. Lipton SA. Pathologically Activated Therapeutics for Neuroprotection. Nat Rev. (Neuroscience). 2007; 8: 8038

7. Shahib MN, Syamsunarno MRAA, Faried A, Yuliana D, Anggraeni, Yuniarti, et al. The effect of Glycine max Extract Diets on Changes in NR2B Gene Expression, Cognitive Vitality and Neurotoxicity in High Concentrate Consumption. Kitakanto Med. J. 2010; 60: 41-7

8. Hansen KB,Osborne HB, Egebjerg. Pharmacological Characterization of Ligands at Recombinant NMDA Receptor Subtypes by Electrophysiological Recordings and Intracellular Calcium Measurements. Combinatorial Chem \& High Throughput Screening. 2008; 11: 304-15

9. National Agricultural Library USDA. USDA National Nutrient Database for Standard Reference, Release 23. 2010 [cited June 11, 2011]. Available from http://www.nal.usda.gov/fnic/foodcomp/cgibin/list_nut_edit.pl

10. Aarts MA, Tymianski M. TRPMs and Neuronal Cell Death. Pflugers Arch - Eur J Physiol. 2005; 451: 243-49 